СИНТЕЗ ТА АНАЛІЗ БІОЛОГІЧНО АКТИВНИХ РЕЧОВИН

Recommended by Doctor of Chemistry, professor M.Ye.Blazheyevskiy

UDC 547.789:543.51:543.544.5.068.7

\title{
OPTIMIZATION OF THE DETECTION CONDITIONS FOR THE SERIES OF 1,2,4-TRIAZOLE-3-THIONES FOR FIA-ESI-MS AND HPLC-ESI-MS
}

\author{
B.O. Varynskyi, A.G.Kaplaushenko \\ Zaporizhzhya State Medical University
}

Key words: flow injection analysis (FIA); high performance liquid chromatography (HPLC); mass-spectrometry (MS); electrospray ionization (ESI); 1,2,4-triazole-3-thions; optimization; polynomial regression

\begin{abstract}
Development of methods for determination of 1,2,4-triazole-3-thiones as intermediate substances in the synthesis of 1,2,4-triazole-3-thioacetate acids salts as potential drugs is an important task at the research and production stage. The study of absorption, distribution, metabolism and excretion requires development of the corresponding methods. The most universal and selective methods used in these cases is the HPLC-MS. The aim of this study was to optimize the conditions of mass spectrometric detection for FIA-MS (flow injection analysis with mass-spectrometric detection) and HPLC-MS (high performance liquid chromatography with mass-spectrometric detection) with the electrospray ionization of eight 1,2,4-triazole-3-thiones by three factors of full factorial design and polynomial regression equations. The work has been performed using the technique of direct sample introduction into the ion source (flow injection analysis - FIA) on an Agilent 1260 Infinity HPLC system with an Agilent 6120 single quadrupole mass spectrometer. The equations of polynomial regression dependence of the signal intensity of the mass detector on three important factors such as the gas drier temperature, the fragmentor voltage and the nebulizer gas pressure have been calculated for the substances studied. Based on the location of the maxima of the functions obtained the optimal values of these factors have been determined. The choice of optimal conditions of mass spectrometric detection allows to maximize the signal on the detector and thus to increase the sensitivity and selectivity of determinations.
\end{abstract}

Currently, there are many derivatives of 1,2,4-triazoles with a high biological activity. They are potential or already widely used drugs. Development of control methods of synthetic stages for compounds of this class at the research and production stage is an important task for modern pharmaceutical science. Determining the ability of substances for absorption, distribution, metabolism and excretion (ADME) also needs to create approaches to the analysis of a number of compounds of this range. The high performance liquid chromatography with mass spectrometric detection, particularly with the electrospray ionization (HPLC-ESI-MS) is undoubtedly one of the universal and selective methods providing elucidation of the structure, determination of the molecular weight, quantitative determination of substances. Using the method HPLC-MS is the subject of many works, in which the conditions of mass spectrometric detection are given $[5,6,8,9]$, however, these 1,2,4-triazole-3-thiones have been studied for the first time, and therefore, the current study has relevance, scientific novelty and practical significance. We have not found papers concerning the use of polynomial models for choosing conditions of the electrospray ionization for mass spectrometric detection.

The aim was to optimize the conditions of ionization with electrospray for mass spectrometric detection of HPLC-MS range of 5-R-4-R1-1,2,4-triazoles-3-thiones as intermediates in the synthesis of the corresponding 1,2,4-triazoles-3-thioacetate acids and their salts, some of them have been already registered and some are potential medicines. In particular, these conditions are the gas drier temperature, the fragmentor voltage and the nebulizer gas pressure.

Experimental Part

The device for LC MS is the Agilent 1260 Infinity HPLC System (degasser, binary pump, autosampler, an Agilent 6120 single quadrupole mass spectrometer with ionization in electrospray (ESI); OpenLAB CDS Software. Conditions of the LC-MS study are: 1) the isocratic mode using the buffer solution: $\mathrm{A}, \mathrm{H}_{2} \mathrm{O}(\mathrm{HCOOH} 0.1 \%)$ and solution of organic modifiers: $\mathrm{B}, \mathrm{CH}_{3} \mathrm{CN}(\mathrm{HCOOH}$ $0.1 \%)-50: 50 ; 2$ ) the ion source - API-ES; 3 ) the mode of selective ion monitoring depending on the molecular 
Table 1

Full Factorial Design for determining the detection conditions of the test substances using ESI-MS

\begin{tabular}{|c|c|c|c|}
\hline $\begin{array}{c}\text { No. of the } \\
\text { experiment }\end{array}$ & $\begin{array}{c}\text { The gas drier } \\
\text { temperature, } \\
\mathrm{T}^{\circ}{ }^{\circ} \mathrm{C}\end{array}$ & $\begin{array}{c}\text { The } \\
\text { fragmentor } \\
\text { voltage, } \mathrm{U}, \mathrm{V}\end{array}$ & $\begin{array}{c}\text { The nebulizer } \\
\text { gas pressure, } \\
\mathrm{P}, \mathrm{psi}\end{array}$ \\
\hline 1 & 100 & 0 & 10 \\
\hline 2 & 100 & 0 & 30 \\
\hline 3 & 100 & 0 & 60 \\
\hline 4 & 100 & 150 & 10 \\
\hline 5 & 100 & 150 & 30 \\
\hline 6 & 100 & 150 & 60 \\
\hline 7 & 100 & 300 & 10 \\
\hline 8 & 100 & 300 & 30 \\
\hline 9 & 100 & 300 & 60 \\
\hline 10 & 200 & 0 & 10 \\
\hline 11 & 200 & 0 & 30 \\
\hline 12 & 200 & 0 & 60 \\
\hline 13 & 200 & 150 & 10 \\
\hline 14 & 200 & 150 & 30 \\
\hline 15 & 200 & 150 & 60 \\
\hline 16 & 200 & 300 & 10 \\
\hline 17 & 200 & 300 & 30 \\
\hline 18 & 200 & 300 & 60 \\
\hline 19 & 300 & 0 & 10 \\
\hline 20 & 300 & 0 & 30 \\
\hline 21 & 300 & 0 & 60 \\
\hline 22 & 300 & 150 & 10 \\
\hline 23 & 300 & 150 & 30 \\
\hline 24 & 300 & 150 & 60 \\
\hline 25 & 300 & 300 & 10 \\
\hline 26 & 300 & 300 & 30 \\
\hline 27 & 300 & 300 & 60 \\
\hline & & & \\
\hline
\end{tabular}

weight, SIM; 4) positive polarity; 5) the gas drier rate (nitrogen) $-10 \mathrm{~L} / \mathrm{min}$.

\section{Materials and Methods}

Acetonitrile of the HPLC grade and formic acid (100\%) were supplied by Merck KGaA (Darmstadt, Germany). Ultrapure water $\left(18 \mathrm{M} \Omega \mathrm{cm}\right.$ at $\left.25^{\circ} \mathrm{C}\right)$ was prepared using a Direct Q 3UV Millipore purification system (Molsheim, France).

The following compounds 4-(2-methoxyphenyl)-5(pyridin-4-yl)-2,4-dihydro-3H-1,2,4-triazole-3-thione (1); 5-(furan-2-yl)-4-phenyl-2,4-dihydro-3 $H$-1,2,4-triazole-3-thione (2); 5-(pyridin-4-yl)-2,4-dihydro-3H-1,2,4triazole-3-thione (3); 5-(morpholin-4-ylmethyl)-4-phenyl2,4-dihydro-3H-1,2,4-triazole-3-thione (4); 4-methyl-5(morpholin-4-ylmethyl)-2,4-dihydro-3H-1,2,4-triazole-3-thione (5); 4-ethyl-5-(morpholin-4-ylmethyl)-2,4dihydro-3H-1,2,4-triazole-3-thione (6); 5-(morpholin-4ylmethyl)-2,4-dihydro-3H-1,2,4-triazole-3-thione (7); 5(2-methoxyphenyl)-2,4-dihydro-3 $H$-1,2,4-triazole3 -thione (8) were used. They were synthesized at the departments of Physical and Colloidal Chemistry (the head of the Dept. - Doctor of Pharmacy, associate professor Kaplaushenko A.G.), Toxicological and Inorganic Che- mistry (the head of the Dept. - Doctor of Pharmacy, professor Panasenko O.I.) at the Zaporizhzhya State Medical University; their composition was confirmed earlier [1-4].

\section{Preparation of Solutions}

The sample of the substance solution was prepared by dissolving $1.0 \mathrm{mg}$ of compounds $\mathbf{2 , 4}, \mathbf{7}$ in $1.0 \mathrm{~mL}$ of $50 \%$ acetonitrile. Analytes $\mathbf{1 , 3}$ and $\mathbf{8}$ were dissolved in dimethyl sulphoxide (DMSO). The study was conducted by flow injection analysis (direct introduction of the sample into the ionization chamber without chromatographic separation). The injection volume was $2 \mu \mathrm{l}$.

\section{Statistical Analysis}

The statistical analysis of the results was performed on a personal computer employing Statistica Package v. 8.0 (StatSoft, USA) based on the values of full factorial design and the corresponding peak areas. The polynomial regression equations were determined. The optimal values of factors were found from the equations using Solver (optimization tool for Excel, Frontline Systems, Inc., USA).

\section{Results and Discussion}

Taking into account the opinions of developers in the research sector of hardware and software (Agilent Technologies company) presented in the recommendations of the OpenLAB CDS software system some of the factors of ionization for the mass detector were selected without optimization. According to these data we selected the flow rate of the eluent $-400 \mu \mathrm{l} / \mathrm{min}$, the flow rate of the gas drier $-10 \mathrm{~L} / \mathrm{min}$, the capillary voltage $-4000 \mathrm{~V}$ before planning the experiment.

The objects under research are new derivatives of 1,2,4-triazoles, they have a specific structure, elemental composition, chemical bonds strength. Thus, we decided to optimize the factors affecting the value of the mass detector signal for each compound individually.

To achieve aim of the work the full factorial design by 3 factors was used. The interval for each factor was selected according to the recommendations of the OpenLAB CDS software package. Since the gas drier temperature recommended by the software is $300^{\circ} \mathrm{C}$, but it also depends on the flow rate, the boiling point of the eluent, the gas drier rate and thermal stability of the sample. The eluent contained water, therefore, the temperature of $100^{\circ} \mathrm{C}$ was chosen as minimal. The nebulizer gas pressure was proposed by the software from 20 to $60 \mathrm{psi}$, depending on the flow rate of the eluent. As the minimal value $10 \mathrm{psi}$ was chosen to study a broader range and determine the best value. The fragmentor voltage may vary depending on the nature of chemical bonds, so we varied it from 0 to $300 \mathrm{~V}$. The flow-injection analysis (the method of the sample direct introduction) was used. The full factorial design is shown in Tab. 1. The factors were considered to be the best if they corresponded to the maximal value of the signal peak area of the mass detector. For each new compound of 1,2,4-triazole-3-thione series 27 combinations of factors $\left(3^{3}\right)$ were studied. All in all 216 experiments were conducted. Each combination was repeated three times. Therefore, 648 measurements were done.

The equations of polynomial regression for dependence of the mass detector signal intensity on three factors, such as the gas drier temperature, the fragmentor 
The regression equations and the optimal conditions for mass spectrometric detection of the substances

\begin{tabular}{|c|c|c|c|c|c|c|c|c|}
\hline \multirow{2}{*}{ Substances } & \multirow{2}{*}{$\begin{array}{l}\mathrm{SIM}, \\
\mathrm{m} / \mathrm{z}\end{array}$} & \multirow{2}{*}{ Regression equations } & \multirow{2}{*}{$\mathrm{R}, \mathrm{R}^{2}$} & \multirow{2}{*}{ Fcalc } & \multirow{2}{*}{$F_{f 1, f 2, a}$} & \multicolumn{3}{|c|}{ Optimal conditions } \\
\hline & & & & & & $\mathrm{T}$ & U & $\mathrm{P}$ \\
\hline 1 & 285 & $\begin{array}{l}S=4118250.98-12777.609 \cdot \mathrm{T}+ \\
53.8893833 \cdot \mathrm{T}^{2}+359928.242 \cdot \mathrm{U}- \\
1260.7575 \cdot \mathrm{U}^{2}+104089.817 \cdot \mathrm{P}\end{array}$ & $\begin{array}{l}0.975171 \\
0.950958\end{array}$ & 64.6 & 3.03 & 300 & 143 & 60 \\
\hline 2 & 244 & \begin{tabular}{|l|}
$S=1565874.72-18586.382 \cdot T+$ \\
$51.7684279 \cdot T^{2}+62410.7234 \cdot U-$ \\
$216.66037 \cdot U^{2}+47798.1473 \cdot P$
\end{tabular} & $\begin{array}{l}0.955808 \\
0.913569\end{array}$ & 35.2 & 3.03 & 300 & 144 & 60 \\
\hline 3 & 179 & $\begin{array}{l}\mathrm{S}=-2634692.0+23192.6314 \cdot \mathrm{T} \\
+62.112728 \cdot \mathrm{T}^{2}+637928.295 \cdot \mathrm{U} \\
-2205.3596 \cdot \mathrm{U}^{2}+517198.506 \cdot \mathrm{P}- \\
4891.4904 \cdot \mathrm{P}^{2}\end{array}$ & $\begin{array}{l}0.964899 \\
0.931030\end{array}$ & 44.9 & 3.03 & 187 & 145 & 53 \\
\hline 4 & 277 & $\begin{array}{l}\mathrm{S}=3410900.31-42541.095 \cdot \mathrm{T}+ \\
111.018572 \cdot \mathrm{T}^{2}+122595.835 \cdot \mathrm{U} \\
-458.85424 \cdot \mathrm{U}^{2}+285964.863 \cdot \mathrm{P}- \\
2930.0861 \cdot \mathrm{P}^{2}\end{array}$ & $\begin{array}{l}0.894853 \\
0.800762\end{array}$ & 13.4 & 3.03 & 300 & 134 & 49 \\
\hline 5 & 215 & $\begin{array}{l}\mathrm{S}=2929281.14+5097.55089 \cdot \mathrm{T} \\
+17.001536 \cdot \mathrm{T}^{2}+59439.8118 \cdot \mathrm{U} \\
-252.38307 \cdot \mathrm{U}^{2}+133239.578 \cdot \mathrm{P}- \\
1550.2213 \cdot \mathrm{P}^{2}\end{array}$ & $\begin{array}{l}0.872500 \\
0.761255\end{array}$ & 10.6 & 3.03 & 150 & 118 & 43 \\
\hline 6 & 229 & $\begin{array}{l}S=2421565.82-6703.0294 \cdot T+ \\
16.2619500 \cdot T^{2}+37001.4610 \cdot U \\
-159.09844 \cdot U^{2}+68908.2841 \cdot P- \\
551.18155 \cdot P^{2}\end{array}$ & $\begin{array}{l}0.871407 \\
0.759350\end{array}$ & 10.5 & 3.03 & 100 & 116 & 60 \\
\hline 7 & 201 & $\begin{array}{l}\mathrm{S}=-279018.59+9838.26968 \cdot \mathrm{T} \\
+20.735148 \cdot \mathrm{T}^{2}+59972.0000 \cdot \mathrm{U} \\
-216.85533 \cdot \mathrm{U}^{2}+56634.5387 \cdot \mathrm{P}- \\
555.88194 \cdot \mathrm{P}^{2}\end{array}$ & $\begin{array}{l}0.975704 \\
0.951998\end{array}$ & 66.1 & 3.03 & 237 & 138 & 51 \\
\hline 8 & 208 & $\begin{array}{l}S=5354847.93-55171.225 \cdot T+ \\
143.746231 \cdot T^{2}+43231.8132 \cdot U \\
-139.09561 \cdot U^{2}+36117.971 \cdot P+ \\
496.813383 \cdot P^{2}\end{array}$ & $\begin{array}{l}0.728245 \\
0.530340\end{array}$ & 3.76 & 3.03 & 300 & 155 & 10 \\
\hline
\end{tabular}

voltage and the nebulizer gas pressure, were calculated. The adequacy of the models obtained was checked using Fisher criteria. The calculated value of Fisher's statistics $\mathrm{F}_{\text {calc }}$ for all compounds is more than $\mathrm{F}_{\text {crit }}$ of tabular values for $\mathrm{f}_{1}=3, \mathrm{f}_{2}=23, \alpha=0.05$, and equals 3.03 indicating the significance of the polynomial regression equation. The coefficients of determination $\left(\mathrm{R}^{2}\right)$ for seven compounds are in the range of 0.76-0.95.

When calculating with the help of "Solver" for Excel the optimal values of the factors in determining the maxima of the functions were obtained, the search was converged in probability to a global solution.

The effect of the gas drier temperature on the mass detector signal intensity is generally described as follows: higher temperatures lead to more effective creation of ions, but at the definite temperature the thermal decomposition of molecules and ions of a substance increases [7]. Therefore, it is likely that the maximum intensity must be observed at the appropriate temperature. We found confirmation of this in practice.

Analysing the optimal temperature of the gas drier (Tab. 2) we note the following. Most compounds, which optimal temperature is $300^{\circ} \mathrm{C}$, have the methoxyphenyl or phenyl radical (compounds $1,2,4$ ) in position 4 of the 1,2,4-triazole cycle, the exception is compound $\mathbf{8}$, which has no substituents in position 4 of the 1,2,4-triazole cycle. It can be explained by the fact that introduction of the phenyl radical leads to $\pi-\pi$ conjugation of the 1,2,4-triazole cycle, and it stabilizes the molecule as a whole. This fact correlates with the data obtained in the analysis of compounds $\mathbf{1}$ and $\mathbf{3}$ differing only by the presence of the 2-methoxyphenyl substituent in position 4 of the 1,2,4-triazole cycle of compound 1 and its absence for compound 3 , the optimal temperatures are $300^{\circ} \mathrm{C}$ and $187^{\circ} \mathrm{C}$, respectively (the optimal temperature for compound $\mathbf{3}$ is below than that for compound $\mathbf{1}$ ).

As for the results of the experiment with the substances containing morpholinomethylene substituents in position 5 of the 1,2,4-triazoles nucleus (compounds $\mathbf{4}$, $\mathbf{5}, \mathbf{6}, \mathbf{7}$ ) it should be noted that the high temperature of $300^{\circ} \mathrm{C}$ is optimal for the compound containing phenyl in position 4 (compound 4). For thione without substituent in $\mathrm{N} 4$ the best temperature is $237^{\circ} \mathrm{C}$. Replacement of the methyl substituent to the ethyl one (compounds 5,6 ) creates conditions for reduction of the optimal temperature (from $150^{\circ} \mathrm{C}$ to $100^{\circ} \mathrm{C}$ ). It can be explained by the fact that the phenyl radical stabilizes the compound through $\pi-\pi$ conjugation with the 1,2,4-triazole cycle. 
The absence of the substituent is characterized by the zero effect (7). The electron-donor properties of alkyl radicals increase (from thione 5 to $\mathbf{6}$ ), and it destabilizes compounds.

Researchers from the Agilent technologies company carefully studied the correlation of the fragmentor voltage and the mass detector signal intensity [10]. It can be assumed that with increase in the fragmentor voltage the mass detector signal intensity should decrease because ions break up into fragments more actively. But, as we see from the data obtained by the authors [10], the signal intensity first increases, passes through the maximum, and then it decreases. The voltage on the capillary and the fragmentor applied to the inlet and outlet of the capillary significantly affect transmission of ions into the detector. The voltage also leads to fragmentation of the sample ions. Generally, the higher fragmentor voltage helps transmission of ions through the area of a relatively high pressure between the outlet of the capillary and the inlet to the skimmer. High fragmentor voltage can cause fragmentation that provides the structural information. For compounds that are fragmented with difficulty the increase in voltage usually results in better transmission of ions.

As can be seen from Table 2, the optimal conditions of fragmentation are in the range from 116 to $155 \mathrm{~V}$. This factor depends on the structure of the compound. Thus, for morpholinomethylene derivatives $(4,5,6,7)$ the lowest optimal fragmentor voltage is observed, namely from 116 to $138 \mathrm{~V}$. It can be seen that when shortening the alkyl chain alkyl chain on the methylene group (compounds $\mathbf{6}, \mathbf{5}, 7$ ) the increase in the optimal fragmentor voltage can be observed, i.e. electron donor substituents reduce the stability of molecules. The presence of aromatic substituents stabilizes the molecule as a whole due to $\pi-\pi$ conjugation with the triazole cycle (compounds $\mathbf{1 - 3}, \mathbf{7}, \mathbf{8}$ ).
Prospects for further research. The next step is to study the chromatographic retention of these substances, as well as 1,2,4-triazole-3-thioacetate acids and their salts, as desired products.

\section{CONCLUSIONS}

1. The polynomial regression equations demonstrating dependence of the signal intensity of the mass detector on three important factors such as the gas drier temperature, the fragmentor voltage and the nebulizer gas pressure have been calculated for eight 1,2,4-triazole-3-thiones.

2. Based on the regression equations the optimal conditions of mass spectrometric detection of eight compounds have been calculated by three factors.

3. It has been determined that introduction of phenyl and methoxyphenyl substituents in position 4 of the 1,2,4-triazole cycle leads to greater stability of the compounds to temperature (the recommended temperature of the gas drier is $300^{\circ} \mathrm{C}$ ). Introduction of the electrondonor alkyl substituent in position 4 reduces thermal stability when increasing the chain length; therefore, for ethyl derivatives the lowest temperature $\left(100^{\circ} \mathrm{C}\right)$ is recommended.

4. Reduction of the methylene group in the alkyl chain (compounds 6, 5, 7) increases the optimal fragmentor voltage, i.e. electron-donor substituents reduce the stability of molecules. The presence of aromatic substituents (compounds $\mathbf{1 - 3 , 7 , 8 )}$ stabilizes the molecule as a whole due to $\pi-\pi$ conjugation of the triazole cycle.

5. Determination of the optimal conditions for mass spectrometric detection is necessary to maximize the signal intensity on the detector and thus increase the sensitivity and selectivity of the methods. Since these conditions are somehow specific, the partial separation of the analyte signal from the signal of impurities is possible.

\section{REFERENCES}

1. Каплаушенко А.Г. Синтез, будова і біологічна активність похідних 4-моно- та 4,5-дизаміщених 1,2,4триазол-3-тіону: Автореф. дис. ... докт. фарм. наук.: 15.00.02. / Запорізький держ. мед. ун-тет, 2012. - 43 с.

2. Каплаушенко А.Г., Панасенко О.І., Книш С.Г. та ін. // Фармац. журн. - 2008. - №2. - С. 67-72.

3. Самелюк Ю.Г., Каплаушенко А.Г. // Актуальні питання фармаи. та мед. науки та практики. - 2013. №2. - C. 125-128.

4. Щербіна Р.О., Панасенко О.І., Книш С.Г. та ін. // Актуальні питання фармаи. та мед. науки та практики. - 2014. - №3. - C. 18-21.

5. Cremin P., Kasim-Karakas S., Waterhouse A.L. // J. Agric. Food Chem. - 2001. - Vol. 49. - P. 1747-1750.

6. Gratz S.R., Flurer Ch.L., Wolnik K.A. // J. Pharmac. Biomed. - 2004. - Vol. 36. - P. 525-533.

7. Haverford college. Department of Chemistry. Resources. Instruments. Analysis by Direct Injection on the Agilent LC/MS. http://www.haverford.edu/chem/Agilent\%20Direct\%20Inject.pdf

8. Huang L.-F. // J. Pharmac. Biomed. - 2003. - Vol. 33. - P. 1155-1162.

9. Lin L.-Z. // J. Agric. Food Chem. - 2000. - Vol. 48. - P. 354-365.

10. Takino M. Determination of the metabolites of nitrofuran antibacterial drugs in chicken tissue by LC-ESI-MS, Agilent Technologies, 2003 (application note). 
ОПТИМІЗАЦІЯ УМОВ ДЕТЕКТУВАННЯ РЯДУ 1,2,4-ТРИАЗОЛ-3-ТІОНІВ ДЛЯ ПІА-ЕСІ-МС ТА BEPX-ECI-MC

Б.О.Варинський, А.Г.Каплаушенко

Ключові слова: проточно-інжекційний аналіз (ПІА); високоефрективна рідинна

хроматографрія (BEPX); мас-спектрометрія (MC); іонізація електророзпиленням (ECI);

1,2,4-триазол-3-тіони; оптимізація; поліноміальна регресія

Розробка методів визначення 1,2,4-триазол-3-тіонів як напівпродуктів синтезу солей 1,2,4-триазол-3-тіоацетатних кислот потенційних лікарських препаратів на стадії досліджень і виробництва є важливою задачею. Визначення поглинання, розподілу, метаболізму та виведення потребує розробки аналітичних методів. Найбільш універсальними і селективними методами, використаними в цих випадках, $є$ BEPX-MC. Мета цього дослідження полягала в оптимізації мас-спектрометричної детекції для ПІА-МС (проточно-інжекційний аналіз з мас-спектрометричною детекцією) і ВЕРX-МС (високоефектииної рідинної хроматограсрії з мас-спектрометричною детекцією) з іонізацією електророзпиленням восьми 1,2,4-триазол-3-тіонів по трьох фракторах повного фракторного експерименту і поліноміальних рівняннях регресії. Роботи проводилися з використанням методу прямого введення проби в іонне джерело за допомогою ВЕРХ системи Agilent 1260 Infinity з одноквадрупольним мас-спектрометром Agilent 6120. Були розраховані рівняння поліноміальної регресії залежності інтенсивності сигналу мас-детектора від трьох важливих фракторів: температури газу-осушувача, напруги на фррагментаторі, тиску газу-розпилювача. На підставі максимумів функцій були отримані оптимальні значення цих фракторів. Вибір оптимальних умов мас-спектрометричної детекції дозволяє максимізувати сигнал детектора і таким чином підвищити чутливість і селективність визначення.

\section{ОПТИМИЗАЦИЯ УСЛОВИЙ ДЕТЕКТИРОВАНИЯ РЯДА 1,2,4-ТРИАЗОЛ-3-ТИОНОВ ДЛЯ ПИА-ЭСИ-МС И ВЭЖХ-ЭСИ-МС \\ Б.А.Варинский, А.Г.Каплаушенко}

Ключевые слова: проточно-инжекционный анализ (ПИА); высокоэфффективная жидкостная хроматографрия (ВЭЖХ); масс-спектрометрия (МС); ионизация электрораспылением (ЭСИ); 1,2,4-триазол-3-тионы; оптимизация; полиномиальная регрессия Разработка методик определения 1,2,4-триазол-3-тионов как промежуточных веществ при синтезе солей 1,2,4-тризолтиоацетатных кислот потенциальных лекарственных веществ на исследовательском и производственном этапе является важной задачей. Исследование адсорбции, распределения, метаболизма и экскреции требует создания соответствующих методик. Наиболее универсальные и селективные методы, применяемые в этих случаях, это ВЭЖХ-МС.Целью этого исследования была оптимизация условий масс-спектрометрического детектирования для ПИА-МС (проточно-инжекционный анализ с масс-спектрометрической детекцией) и ВЭЖХ-МС (высокоэффрективная хроматография с масс-спектрометрической детекцией) с ионизацией в электроспрее (ЭСИ) восьми 1,2,4-триазол-3-тионов по 3 фракторам полного фракторного эксперимента и полиномиальным уравнениям регрессии. Работа была проделана техникой прямого ввода образца в ионный источник на Agilent 1260 Infinity HPLC system с одноквадрупольным масс-спектрометром Agilent 6120.Были рассчитаны уравнения полиномиальной регрессионной зависимости сигнала масс-детектора от трех важных фракторов: температуры газа осушителя, напряжения на фррагментаторе, давления газа небулайзера. Оптимальные значения этих фракторов были рассчитаны на основе определения максимумов полученных фрункций. Выбор оптимальных условий масс-спектрометрической детекции позволяет максимизировать сигнал на детекторе и таким образом увеличить чувствительность и селективность определений. 